Душанка С. ВУЈОВИЋ* Универзитет у Новом Саду Филозофски факултет
Прегледни рад

Примљен: 16. 10. 2018. Прихваћен: 03. 12. 2018.

\title{
ЛЕКТОРАТ СРПСКОГА ЈЕЗИКА И ЈЕЗИКА ДРЖАВА БИВШЕ ЈУГОСЛАВИЈЕ НА СЛАВИСТИЧКОМ ИНСТИТУТУ УНИВЕРЗИТЕТА У КЕЛНУ - ПРЕГЛЕД И ПЕРСПЕКТИВЕ ${ }^{* *}$
}

\begin{abstract}
Институт за славистику у Келну основан је 1953. године као један од првих института за словенску филологију који су се појавили у Западној Немачкој после Другог светског рата. Основао га је професор Рајнхолд Олеш, који је био и први предавач српскохрватског језика. Српскохрватски језик је као предмет уведен одмах по оснивању Института, већ у зимском семестру 1953/1954. године. Главни предмет на славистичким студијама тада је био руски језик и књижевност, а од осталих словенских језика одмах после руског уведени су пољски, српскохрватски и чешки језик. Келнски лекторат је један од ретких лектората где се, додуше у смањеном обиму, још увек предаје српски језик. У раду се даје преглед наставе српског језика, прво као српскохрватског, а онда и у групи са осталим језицима држава бивше Југославије, од оснивања Института до данас. Келн.

Кључне речи: србистика, сербокроатистика, лекторати, Институт за славистику,
\end{abstract}

Изучавање славистике, осим у земљама словенског говорног простора, најзаступљеније је, из геополитичких разлога, у Немачкој, Аустрији и деловима Швајцарске. У Немачкој је после Другог светског рата па све до 90-их година XX века број универзитета са славистичким катедрама и институтима растао. Како извештава Ж. Марковић, почетком 90-их година било је „близу 40 универзитета у Немачкој у чијем је саставу постојао институт, одн. семинар за славистику” (Марковић 1997). ${ }^{1}$ У оквиру бројних славистичких

\footnotetext{
"dusanka.vujovic@ff.uns.ac.rs

** Рад је настао у оквиру пројекта Стандардни српски језик: синтаксичка, семантичка и прагматичка истраживања (178004), који финансира Министарство просвете, науке и технолошког развоја Републике Србије.

${ }^{1}$ Преглед свих славистичких института у Немачкој са линковима ка њиховим веб-сајтовима може се наћи на интернет страници удружења немачких универзитетских наставника славистике (http://www.slavistenverband.de/Links.html). Веб-сајт славистичког института у Потсдаму даје
} 
института, поред лектора других словенских језика, наши лектори су држали часове српскохрватског језика и књижевности и културне историје. Тако је било све до 90-их година и распада југословенске државне заједнице, чија је једна од последица било и укидање Републичког завода за међународну научну, културну, техничку и просветну сарадњу, који је имао задатак, поред осталог, и да брине о лекторатима. Од тада брига о лекторатима није била институционализована тако да су лектори путем међуфакултетских договора, а понекад и путем приватних контаката, одлазили на лекторате. Лектори који су остајали у већ постојећим лекторатима и њихови наследници били су или из Србије или из Хрватске па су тако по некаквој инерцији и остајали српски или хрватски лекторати, али на универзитетима у Немачкој језик који се проучавао у првим годинама после распада Југославије, и поред тога, остао је углавном у свом називу, српскохрватски. То што се језик на универзитетима у Немачкој није раздвојио посебно на српски и хрватски има везе, са једне стране, са укупно смањеним интересовањем студената за сербокроатистику, али и са смањењем финансија које је тих година немачка држава одвајала за универзитете.

Кад говоримо о лекторатима у Немачкој, распад Југославије се поклопио са периодом у коме су у читавој Немачкој смањили и ограничили финансирање универзитета, тако да је наш језик, пошто спада у тзв. „мале” словенске језике, бивао међу првима на удару и многи наши лекторати су почели један по један да се гасе и затварају. Разлог томе било је, осим смањеног интересовања за сербокроатистику и то што наша држава није учинила много како би задржала лекторате који нису могли да буду финансирани у потпуности од стране државе домаћина. Како није било воље или могућности да се плате наших лектора суфинансирају, полако су се гасили лекторати и та тенденција постоји и данас не само у Немачкој него широм света. Осим тога, ширење процеса глобализације потпомогнуто муњевитим развојем информационих технологија чини се да се поклапа са смањењем интереса за хуманистичке науке уопште, а посредно и за језике, поготово за словенске језике.

Институт за славистику на Филозофском факултету у Келну основан је 1953. године као један од првих института за словенску филологију који су се појавили у Западној Немачкој после Другог светског рата. Основао га је професор Рајнхолд Олеш (1910-1990) са идејом да то буде центар у коме ће се изучавати широк спектар словенских језика. У оквиру Института постојале су две катедре, једна за књижевност и друга за лингвистику.

Рајнхолд Олеш је био први предавач српскохрватског језика, који је уведен у наставни план већ у зимском семестру 1953/1954. године. Главни предмет на славистичким студијама тада био је руски језик и књижевност, а од осталих словенских језика одмах после руског уведени су пољски, српскохрватски и чешки језик. Професор Олеш је био слависта широког образовања који се посебно бавио несталим словенским језицима и дијалектима

и линкове ка славистичким институтима у Аустрији и Швајцарској (http://www.uni-potsdam.de/ u/slavistik/ slavinst.htm). 
који нестају из словенских језика. Одатле потиче и његово интересовање за чакавско наречје и услед тога повезаност са хрватским лингвистима. Под његовом управом почела је сарадња са лекторима за српскохрватски језик. Испочетка су то били углавном угледни хрватски лингвисти. То потврђује и чланак Михаела Милера у раду „Србистика у Келну”, у ком он каже да су на место лектора српскохрватског језика у Институт за славистику у Келну долазили углавном већ реномирани професори који су за тај посао обично бивали преквалификовани (Милер 2014: 293). На то указује списак оних који су гостовали у Келну од 1959. године.

Од оснивања Института 1953. године, професор Олеш је српскохрватски језик предавао повремено, све до 1959. године, када на место лектора долази реномирани хрватски лингвиста Мате Храсте (1897-1970). Мате Храсте је пре доласка у Келн држао Катедру за историју језика и дијалектологију на Филозофском факултету у Загребу. Са професором Олешом делио је интересовања за дијалектологију, а посебно за чакавско наречје. Из тог интересовања поникао је пројекат Чакавски лексикон (Čakavische Lexikon), који су касније, након његове смрти, од 1979. до 1983. године, довршили и у три тома издали Петар Шимуновић и Рајнхолд Олеш. ${ }^{2}$

У два наврата, између 1964. и 1968. године и 1973. и 1975. године, у келнском Институту за славистику боравио је и радио и познати хрватски лингвиста Људевит Јонке (1907-1979), који је у Келн дошао са позиције управника Катедре за савремени хрватски књижевни језик. Важно је напоменути да су и он и Мате Храсте били потписници Новосадског књижевног договора.

Од 1969. године лекторат преузима историчар књижевности и књижевни критичар и преводилац Иво Франгеш (1920-2003), који је на Филозофском факултету у Загребу водио Катедру за новију хрватску књижевност. Осим практичних лекторских вежбања он је држао предавања из Историје хрватске књижевности.

Франгешов наследник био је познати хрватски историчар књижевности Мирослав Шицел (1926-2011), који је у Келн дошао 1971. године, као и Франгеш, са Катедре за новију хрватску књижевност. Он је држао предавања из Хрватске књижевности на прелазу из 19. у 20. век.

Истакнути хрватски лингвиста Милан Могуш (1927-2017) боравио је у Келну у зимском семестру 1969/1970. као и 1974. године. У Институт је дошао са позиције управника Катедре за дијалектологију и историју хрватског језика. Поред практичне лекторске наставе предавао је Историјску фонологију и Историјску граматику хрватскосрпског језика.

У реду значајних хрватских лингвиста који су предавали у Институту за славистику нашао се и познати дериватолог Стјепан Бабић (1925). Он је 1984. и 1985. године, уз лекторске вежбе, држао курс Творба речи у српскохрватском језику.

${ }^{2}$ M. Hraste/P. Šimunović: Čakavisch-deutsches Lexikon. Teil I. Unter Mitarbeit und Redaktion von R. Olesh; R. Olesh/P. Šimunović (Hg.): Čakavisch-deutsches Lexikon. Teil II. Deutsches Wortregister; R. Olesh/P. Šimunović (Hg.): Čakavisch-deutsches Lexikon. Teil III. Čakavische Texte, Köln, Wien 1979-1983 (=Slavische Forschungen 25/I-III). 
Петар Шимуновић, лексиколог и ономастичар, у Келн је дошао 1994. године и био је последњи из реда хрватских знаменитих лингвиста који су гостовали у Институту за славистику. Држао је разне курсеве до 1998. године. То су били Историја хрватског/српског језика, Хрватски/српски дијалекти, Хрватски и српски народни језик и др. Наравно уз сва предавања, као и остали лектори, држао је и практичне лекторске вежбе. ${ }^{3}$

Професор Улрих Обст, који је у Келн дошао 1986. из Минстера на место шефа Института, 1999. године одлучио је да прекине дугогодишњу традицију сарадње са хрватским лингвистима и упутио позив на сарадњу Филозофском факултету Универзитета у Новом Саду. Желео је да од 2000. године место лектора преузме неко из Србије, односно из Новог Сада, тако да је у летњем семестру 2000. године на место доцента за српски и хрватски језик дошао Жељко Марковић са Одсека за српски језик и лингвистику Филозофског факултета у Новом Саду. Колегу Марковића наследила је 2005. године Душанка Вујовић, која је остала у Институту све до 2009. године када је, из финансијских разлога Институт био приморан да укине један лекторат. Пошто су остали лекторати били заштићени међудржавним уговорима, као нпр. бугарски лекторат, или су били суфинансирани од стране својих држава као нпр. словачки лекторат, логичан избор је био да се укине српски/хрватски лекторат чије суфинанирање, у том тренутку, држава Србија није обезбеђивала. То се све дешавало у веома тешко време за келнски Славистички институт јер су од 2009. године постепено смањивали професорска и административна места на славистици да би 2010. године Институт био пресељен из зграде у којој се налазио од 1958. у зграду Филозофског факултета тзв. Филозофикума.

Институт се од 1958. године налазио у тзв. жутој вили у Вејерталу. То је била велика лепа кућа на два спрата у оквиру универзитетског кампуса, у којој је Славистички институт радио годинама. У подруму и у приземљу налазиле су се канцеларије и библиотека са читаоницом, ${ }^{4}$ на првом и другом спрату простор преуређен у учионице и кабинети професора. Стално је било пуно студената, сви сарадници су били љубазни и срдачни тако да се у том простору увек осећао дух словенског заједништва. Често су се у вили одржавале књижевне и филмске вечери, промоције књига и прославе. Обавезна је била божићна прослава на коју су долазили сви сарадници и пријатељи Института, прослава православне Нове године и прослава краја наставе у летњем семестру која се обележавала роштиљем у дворишту Института, где су се увек доносила словенска национална јела и пића. Са наше стране лектори су обично доносили српске специјалитете, што је увек било радо прихваћено. На прославе су, осим сарадника, увек били позивани и студенти.

\footnotetext{
${ }^{3}$ Осим поменутих лингвиста, у келнском Институту за славистику, на месту сарадника за српскохрватски језик неко време су провели и Антон Кнежевић, Љерка Секулић, Фран Петре, Мира Филиповић, Милан Ратковић, Јосип Вончина, Златко Винце, Марко Самарџија, Данијел Варга, Цвјетко Милања, Јосип Кекез, Душан Маринковић, Драгослав Јовановић, Елвира Веселиновић.

${ }^{4}$ Библиотека Института за славистику, са својих скоро 150.000 књига, једна је од најбоље опремљених славистичких библиотека у читавој Немачкој.
} 
Приликом тих сусрета рађала су се пријатељства, али и ницале идеје за нове пројекте. Институт је био организатор многих симпозијума, међу којима је и симпозијум посвећен српским језичким, књижевним и историјским темама под називом Србија у контексту - литература, језик, историја (Serbien im Kontext-Literatur, Sprache, Geschichte) који је одржан 29. јуна 2007. Реферати са тог симпозијума уобличени су 2010. у зборник Србија - криза идентитета као континуум (Serbien - Identitätskrise als Kontinuит).

Што се тиче наставе, сербокроатистика се раније у Келну студирала као споредан студијски предмет у оквиру тзв. магистарских студија. Магистарске студије у Немачкој су подразумевале могућност избора три области студирања, од којих је једна главна и две споредне. Пошто је било могуће комбиновати разне предмете филолошких и нефилолошких профила, било је студената који су студирали рецимо, кинески, енглески и славистику или филозофију, историју и славистику итд. Студенти који су студирали славистику као главни избор, имали су обавезан један јужнословенски језик и зато је увек било оних који су бирали српскохрватски, који је након распада Југославије 90-их година постао интересантан студентима разних профила из геополитичких разлога. Није била реткост да студенти којима је главни предмет била историја, географија или политичке науке бирају да уче српскохрватски језик. Наравно, не треба занемарити ни велику дијаспору у Немачкој. Много je деце која су пореклом са бившег југословенског простора или из мешаних бракова, која су обично, из породичних разлога, бирала српскохрватски језик.

Настава српскохрватског, односно хрватског и српског језика, како се звао крајем 20. и почетком 21. века, подразумевала је 16 часова недељно, од чега је 10 часова било резервисано за практичне лекторске вежбе које су обухватале пет језичких нивоа: Grundkurs 1, 2, 3 и Oberkurs 1, 2, а 6 часова било је посвећено теоријским предавањима. Лектор је био слободан у избору тема за предавања, и у сваком семестру је, у оквиру часова семинара, морао да држи нову тему. Тако су они лектори који су се бавили лингвистиком (нпр. Жељко Марковић, Душанка Вујовић) обично бирали лингвистичке теме, а они који су се бавили књижевношћу бирали су теме из књижевности. У оквиру часова просеминара, теме су се понављале, у једном семестру било је обавезно предавати историју језика на курсу Uvod u serbokroatistiku, а у другом семестру је то било упознавање са културном историјом и геополитиком државе, на курсу који се звао Landeskunde.

Шта можемо рећи о називу језика? До 1993. године језик који се нудио студентима звао се српскохрватски (Serbokroatisch), од 1994. упоредо са ьим уводи се дводелни назив хрватски и српски (Kroatisch und Serbisch), а после 1994. године у свим називима курсева користи се само хрватски и сриски (Kroatisch und Serbisch). Као што је и данас на многим универзитетима уведен троделни назив босански-хрватски-српски (BCS Bosnisch/Kroatisch/ Serbisch), тако је било једно време и у Келну. Након поновног отварања нашег лектората у зимском семестру 2016/2017. године, у назив су додати, осим босанског и црногорски језик тако да се сада лекторат прилично рогобатно зове босанско/хрватско/црногорско/српски лекторат (Bosnisch/Kroatisch/ 
Montenegrinisch/Serbisch) мада је и даље на неким местима у документима задржан назив српскохрватски. Појављује се, рецимо, уз име наше лекторке: Dr. Dragana Grbić Lektorin für Serbokroatisch; или у називима курсева у распореду наставе као Serbokroatisch 1, 2 ili Serbokroatisch-grammatik и сл.

После вишегодишње паузе, од зимског семестра 2016/2017. године, углавном захваљући професору Даниелу Бунчићу, сербокроатистика се поново вратила у Келн. Обезбеђена су средства за пола наставног фонда, што значи осам часова недељно. Тренутно је тамо лекторка из Београда Драгана Грбић.

Међутим, проблем је и даље то што за нашег лектора пола наставног фонда значи и пола плате, са чим се могу покрити само основни, минимални трошкови боравка у Немачкој. Надамо се да ће новим Правилником о лекторатима који је израдила Радна група за лекторате у Министарству просвете, науке и технолошког развоја та ситуација бити поправљена. У том Правилнику је предложено да се у будућности наши лекторати, тамо где постоји потреба, суфинансирају.

Данас се Институт за славистику у Келну налази на тамошњем Филозофском факултету и припада групи предмета (фахова) бр. 5 односно, тзв. студијском програму „Савремени језици и културе”. Свој програм Институт за славистику нуди као заједнички студијски програм Регионалних студија источне и централне Европе у сарадњи са Економским факултетом, Факултетом друштвених наука и Правним факултетом. Због тога, перспектива саме сербокроатистике у Келну, а и у читавој Немачкој, није сјајна. Број часова се, вероватно, неће нигде повећати, али могућности сарадње се продубљују увођењем двојног мастер програма Културна и интелектуална историја између Истока и Запада, који пружа могућност студентима оних универзитета који имају потписан споразум о сарадњи са Универзитетом у Келну да добију две мастер дипломе - прву на свом матичном универзитету и другу на Универзитету у Келну. Програм нуди креативни и интердисциплинарни простор за студирање и истраживање, а превасходно је усмерен на културно-филолошке и историјске студије. У средишту истраживачке пажње пожељно је да буду везе између источне и западне Европе и њихово заједничко културно наслеђе. Студенти након завршетка овог мастера могу да наставе студије у оквиру двојних докторских студија (Cotutela-Promotion). Стипендије за овај програм могу се остварити преко Еразмуса или преко Института за славистику.

Иако будућност србистике и сербокроатистике у Келну, а и у читавој Немачкој, тренутно не изгледа светла, учешћем наше државе у институционализацији бриге о лекторатима и у суфинансирању лектората, побољшањем сарадње са институтима и центрима у којима имамо наше лекторе, разменом литературе, подршком двојним мастерским и докторским студијама, евентуалним стипендијама за стране студенте и бригом о нашим лекторима, верујем да ће се отворити и нове могућности за лекторате како у Немачкој тако и у свету. Наши лектори у иностранству промовишу наш језик и нашу културу стварајући једну општу позитивну слику о нама због чега би требало да буду један од важних националних интереса наше државе. 


\section{ЛИТЕРАТУРА}

Марковић 2007: Ž. Marković, O položaju srbistike na univerzitetima u Nemačkoj, Savremene tendencije u nastavi jezika i književnosti, Beograd: Filološki fakultet, 412-417.

Милер 2010: Hg. von M. Müller, Serbien-Identitätskrise als Kontinuum. Äußere und innere Wandlungen in Literatur, Sprache und Geschichte, Schriftenreihe des Zentrums Osteuropa, Band 2, Köln: Kirsch-Verlag.

Милер 2014: М. Müller, Serbokroatistik in Köln, u Die gelbe Villa im Weyertal - Sechzig Jahre Slavisches Institut der Universität zu Köln (1953-2013), Hg. von Bodo Zelinsky, Köln: Zentrum Osteuropa der Universität zu Köln: Kirsch-Verlag, 292-298.

Dušanka S. Vujović

SERBISTIK IN KÖLN - RÜCKBLICK UND PERSPEKTIVEN

Zusammenfassung

Slavisches Institut der Universität zu Köln blickt auf eine lange Tradition zurück und wurde im Jahre 1953 als eines der ersten Institute für die slavische Philologie in der Bundesrepublik Deutschland nach dem Zweiten Weltkrieg gegründet. Sein Begründer war Reinhold Olesch, der schon im Schuljahr 1953/54 das Studium der serbokroatischen Sprache neben dem Russischen, Polnischen und Tschechischen eingeführt hat. Das Lektorat in Köln gehört zu den nicht so zahlreichen Lektoraten, an denen noch immer Serbisch unterrichtet wird, eigentlich in geringerem Umfang.

In diesem Beitrag wird der Unterricht der serbischen Sprache dargestellt, zuerst als Studium des Serbokroatischen, und danach als Studium der Sprachen des ehemaligen Jugoslawiens, und zwar von Begründung des Instituts bis heute.

Obwohl die Zukunft der Slavistik und Serbokroatistik in Köln und im ganzen Deutschland ziemlich ungewiss ist, werden aber auch neue Perspektiven für die Lektorate in Deutschland und in der Welt eröffnet und zwar durch die folgenden von unserem Land durchgeführten Maßnahmen: Unterstützung und Förderung der Lektorate und Lektoren, verbesserte Kooperation mit den Zentren, in denen wir unsere Lektoren haben, durch den Literaturaustausch, Unterstützung und Förderung der Zwei-FachMaster- und Doktoratsstudien und Fördermöglichkeiten und Stipendien für Auslandsstudenten.

Schlüsselwörter: Serbistik, Serbokroatistik, Lektorate, Slawisches Institut, Köln. 